\title{
FROM THE REVOLUTION OF DIGNITY TO DESPAIR: A REFLECTION ON THE BORDER REGIONS OF UKRAINE
}

\author{
Eugenia Maruniak ${ }^{\text {, Sergiy Lisovkyi }}$ \\ Institute of Geography, National Academy of Sciences of Ukraine \\ 44, Volodymyrska str., Kyiv, 01054: Ukraine \\ emgeooffice@gmail.com•salisovsky@gmail.com
}

\begin{abstract}
This article offers a detailed analysis of the content characterising the geopolitical challenges and socio-economic changes that have been facing Ukraine in the years following the Revolution of Dignity, as well as interregional differences. The focus here is on administrative regions of Ukraine that border on to EU Member States, while the special emphasis is on the Ukrainian-Polish border regions, i.e. those in which the cooperation put in place can be regarded as most successful and intensive of all. Furthermore, as gaps to the availability of statistical data are present, the main emphasis has been on case studies, content and SWOT analysis, the search for good practice, and typical patterns of perception as markers of the dynamics present in social space.
\end{abstract}

Keywords: cross-border cooperation, electoral space, identity, regional development, Poland, social space, Ukraine.

\section{Introduction}

The issues of the development of border regions and cross-border cooperation have long been on the agenda of EU Member States, and these also gained in relevance over in Ukraine at the beginning of the 21st century, given that as many as 19 of Ukraine's 25 regions are actually border regions. In 2004, Ukraine adopted its Act on Cross-Border Cooperation, which lays down a concept for the euro-region and for cross-border cooperation, while also enshrining a goal that good neighbourly relations should be put in place, with cooperation between entities and participants in cross-border cooperation enhanced, given the contribution that can be made to both local and regional development.

The first euro-region, of the 'Carpathians', was established long before the relevant law was passed, in 1993. Nearly two decades later, the EU instruments under the cross-border cooperation programme, available to Ukraine within the framework of the European Neighborhood and Partnership Instrument concern 'Hungary-Slovakia-Romania-Ukraine', 'Ukraine-Poland-Belarus', 'Ukraine-Romania-Moldova' and 'the Black Sea'. These programmes at the moment encompass the Volyn, Zakarpattia, Ivano-Frankivsk, Odessa, Lviv, Rivne, Ternopil and Chernivtsi regions of Ukraine ${ }^{1}$.

${ }^{1}$ And annexed Crimea. 
It should be noted that the intensity of cooperation is different in Ukraine's western, northeastern, and eastern border regions, and that, while this reflects the impact of many factors, it is primarily those of an economic nature that are responsible. At the same time, historical factors have also exerted a significant impact (related to the polities Galicia, Transcarpathia and Bukovina, which - prior to Ukraine's incorporation into the USSR - formed part of the Austro-Hungarian Empire for over a century); as have models of social behaviour in a population characterised (in western regions at least) by such features as high mobility, entrepreneurship, and wider family and public communication. It was the inhabitants of western regions who, as early as back in the 1990 s, became locomotives of the labour-migration process, with the results being both outflows of working-age population and significant inflows of foreign currency, as well as localised investments in individual construction and small businesses.

There is no doubt that the phenomenon often dubbed 'migrant work' has supplied Ukraine, and especially its border communities, with more than just money and a certain level of wellbeing. This reflects vision as to the values and living standards present in the EU, which have become models for quality of life in the Ukrainians' own country. These influences have spread farther away from the border to Zhytomyr, Khmelnytsky and Cherkasy regions, but remain less pronounced than in the border regions.

Therefore looking quite as expected are the electoral tastes of the inhabitants from western Ukrainian regions, with their clear preference for pro-European and centrist forces (even as some support right-wing movements), as well as support shown for both the Orange and Dignity Revolutions, in which representatives from the Lviv, Volyn, Ternopil and Ivano-Frankivsk regions were among the main driving forces.

At the same time, these people had really high expectations for both Revolutions that include, not only hope as regards economic growth and official steps towards European integration (implemented to some extent since 2005), but also changes in regard to government approaches, the business environment, and the achievement of spatial justice. However, along this path, there have been and remain obstacles of several different types, i.e. unprepared political elites (at the level of 'critical mass'), resistance provided by parties strongly opposed to the changes, difference of opinion about public welfare, justice and the ways to ensure it within different social groups and, finally, a certain inertia of processes extending the period between decision-making at government level and visualisation of results among end-users. The reform achieving greatest success in the years 2014-2019 entailed decentralisation, as intended to strengthen local authorities and ensure the establishment (by unification) of new territorial authorities based on the European model. However, it has not emerged as a tool mitigating social disparities more significantly, and accelerating the implementation of European values at the expected level.

The first 'inter-revolutionary' disappointment thus led to a revanche of the pro-Russian and partially pro-communist Party of Regions and then a second 'post-Maidan' one led to a strengthening of oligarchic influences and a wave of populism and uncertain geopolitical stakes. Ultimately, the COVID-19 pandemic was a significant challenge, affecting both the global and regional economies in 2020, and serving to raise inequalities and imbalances, and to exacerbate social problems.

This article seeks to provide a more-detailed analysis of regional-identity issues, as well as some features of the population in certain regions' responses to geopolitical, geo-economic and social challenges, the consequences of such reactions as exemplified by the situation of a western border particularly important to further EU-Ukraine cooperation, as well as the shaping of coordinated government policy. 


\section{Conceptual background and methodology}

The uneven distribution of objects and phenomena in space, peculiarities to the way this is perceived and approaches to processes of transformation have always remained the focus of research into, and the shaping of, various relational and post-structural concepts, and, ultimately, their combination. The noteworthy vector is, of course, the impact on the understanding of space in the geography of the human factor, or the general trend regarding humanisation and anthropogenisation. It is about understanding space-time as a measure of the effort exerted to cover distance (Janelle, 2001) and, in essence, these views are close to the concept of accessibility of place, and, accordingly, likely competitive advantage. Such considerations are i.a. deepened by the spatial-temporal concept after P. Forer (1974), which brings together the spatial structure of society, the nature of investment processes and the spatial-temporal convergence of P. Adams (1995), who addresses the ability of an individual or institution to spread its influence through space and time through mass media and other available means, as well as the image of the territory. Yet another notion of relevance here is that involving social justice and uneven development, as proposed by D. Harvey (2006). What is mentioned here is the representation of space (as conceptualised) and the space of representation (as lived in). Probably of key importance as regards the interpretation of space is H. Lefebvre's concept of 'space production' (1991) which holds that the concepts of 'spatial practice', 'spatial representation' and 'representational space' may denote certain important associations and perceptions.

The problem of territorial identity - defined as the perception of place in the course of a process of interaction with it - should be especially relevant, while place is 'the center of values, built on experience' (Tuan, 1974, 1977), with a sense of place being influenced by racial, ethnic or class features (Rose, 1995), while the relationship of identity that connects a community with the lived space is 'identity that links a given community to its lived space' (Caldo, 1996), and we consider 'the presence of socio-economic context conditions allowing convergence between collective and private interests, and feeding a sense of belonging and loyalty to a community' (Capello, 2019). So it is that the territorial identity of a population may prove key to the development of both regions and a state as a whole, determining the success achieved implementing certain management models, patterns of mobility and reproduction, and perceptions of external influences.

Even more special than territories or regions in general are border areas, which - depending on the characteristics of the border in question - serve mainly in either barrier functions or integration functions, in any case being exposed to the influence of other, neighbouring identities, the further retransmission of which may follow different scenarios. In addition, the stereotypes obtained in the process of integration can be adapted in different ways in line with the system of values present within border localities, in particular ethno-cultural, linguistic and religious closeness, the institutional environment, the degree of central-government influence and the level of trust that the latter is able to achieve.

Geopolitical and geo-economic aspects also play an important role. The concept of the socalled 'clash of civilizations' (Huntington, 1993), though not always fully discernable in different countries and regions, still rightly defines the 'pain points' of interaction between neighboring states, especially on post-Soviet territory. However, Huntington's presentation of Russia's role as a 'core' of Orthodox civilization could be the subject of some criticism. The latter is now a rather vague concept, given that, both politically and socio-economically (and to some degree also religiously) most of the countries supposedly forming it already belong to (or have demonstrated their intention to join) Western civilisation. 
Geo-economics, given the obvious dynamics of globalisation processes only interrupted by the spread of the COVID-19 pandemic in 2020, adds its conflict potential to the development of border areas. On the one hand, there are risks of distancing and alienation due to possible marginalisation in the global landscape; while on the other there are additional source of conflicts depending on the multidirectional aspirations of centres of influence (the USA and EU, China and Russia).

Another concept to be mentioned in the context of this study is that of governance, as 'the capacity of government to make and implement policy, in other words, to steer society' (Kjar, 2004, p. 10), or, according to F. Fukuyama (2013), the government's ability to develop and apply rules and also provide services regardless of how democratic it is. In fact, Fukuyama goes on to identify 'four broad approaches to assessing the quality of governance: procedural measures, input measures, output measures, and measures of bureaucratic autonomy' (Fukuyama, 2013, p. 5). At the same time, one way or another, issues of the level of management networks development, management culture, as well as the level of its centralisation arise because, in the developed democracies, the role of local governments is growing, and such 'communitarian governance' is considered suitable for solving community-development problems without excessive public bureaucracy (Pierre \& Peters, 2000).

It is the study of cross-border cooperation that many publications and projects both in the EU and in Ukraine are devoted to. In Europe, the process of building cross-border connections began in the 1970s, in fact with the 1971 establishment of the European Association of Border Regions (AEBR). In general, it has lasted successfully for many years, especially with the advent of Interreg programs. This has contributed, not only to a solving of the common problems of individual territories, but also to better redistribution of resources and the achievement of territorial cohesion, though some challenges and conflict potential have also been noted by researchers (Perkmann, 2003).

In Ukraine, the topic of the development of border regions and cross-border cooperation has remained one of the most popular, especially in the period 2000-2010. At the same time, it should be noted that the subjects of research were mainly economic, financial and institutional issues (Maksymenko, Kish, Lendie \& Studennikov, 2000; Kostyuk, 2004; Mikula, 2004). At the end of the first decade of the 21st century, there was a growing interest in the geopolitical context along almost the entire border region, and especially the Russian-Ukrainian sector (Popkova, 2005; Pirozhkov, 2002; Podgrushny, 2010; Kolosov \& Vendina, 2011), this being supported within the framework of both inter-academic cooperation and other sources. The background of such Russian interest became apparent in 2014, following the annexation of Crimea and the occupation of Donbas, as well as numerous attempts to escalate protests in eastern Ukrainian regions. In the second decade, starting 2008-2010, one of the emphases becoming most pronounced involved labour-migration problems, and the prospects for the demographic situation on the labour market these brought about, in relation to western regions in particular (IDSR, 2018).

At the same time, today brings an obvious need to revise and take a comprehensive look at the development of the country's border regions, not only in line with the socio-economic realities and the potential generated by the institutional environment, but also in line with experience gained since independence, the acceptance of the latter by local populations, and markers of that perception in the national electoral and mass-media space.

Accordingly, further research has been based on a holistic approach to the analysis of regional development, which is shaped in line with the historical background and the latest challenges, individual and collective experience. The aim has been to analyse changes taking place in the regions of Western Ukraine following the Revolution of Dignity, as closely tied with a choice orientated towards Europe and an improved quality of life for Ukrainians. 
The first sub-chapter here is thus devoted to analysis of the preconditions underpinning the regional economy and shaping of regional identity. This is a touch of history relating, not only to western regions, but also to 'conflict zones' of past Soviet impact on the Ukrainian present. Subsequent sub-chapters pay significant attention to social patterns and perceptions of changes in regions traditionally considered pro-Ukrainian, and, in addition (due to proximity to the western border), more deeply integrated with certain individual EU countries than with other countries. It is a matter of comparison of official well-being indicators, population change, and electoral behaviour with those markers specifying locals' assessment of state policy, reforms and the situation as a whole. Account is also taken of the impact of the COVID-19 pandemic, which only served to further deepen social disparities. Planning of territorial development and cross-border cooperation have been analysed as possible tools by which policy gaps may be addressed.

Western Ukraine is a macro-region capable of being defined differently by different scholars, in this way covering between three and seven of the modern administrative regions (oblasts) into which Ukraine is divided. The study in fact focuses on the six administrative regions bordering on to EU countries, with a special emphasis being placed on the Ukrainian-Polish border regions, in particular those of Lviv and Volyn, in which the relevant cooperation can be considered the most successful and intensive (Fig. 1).

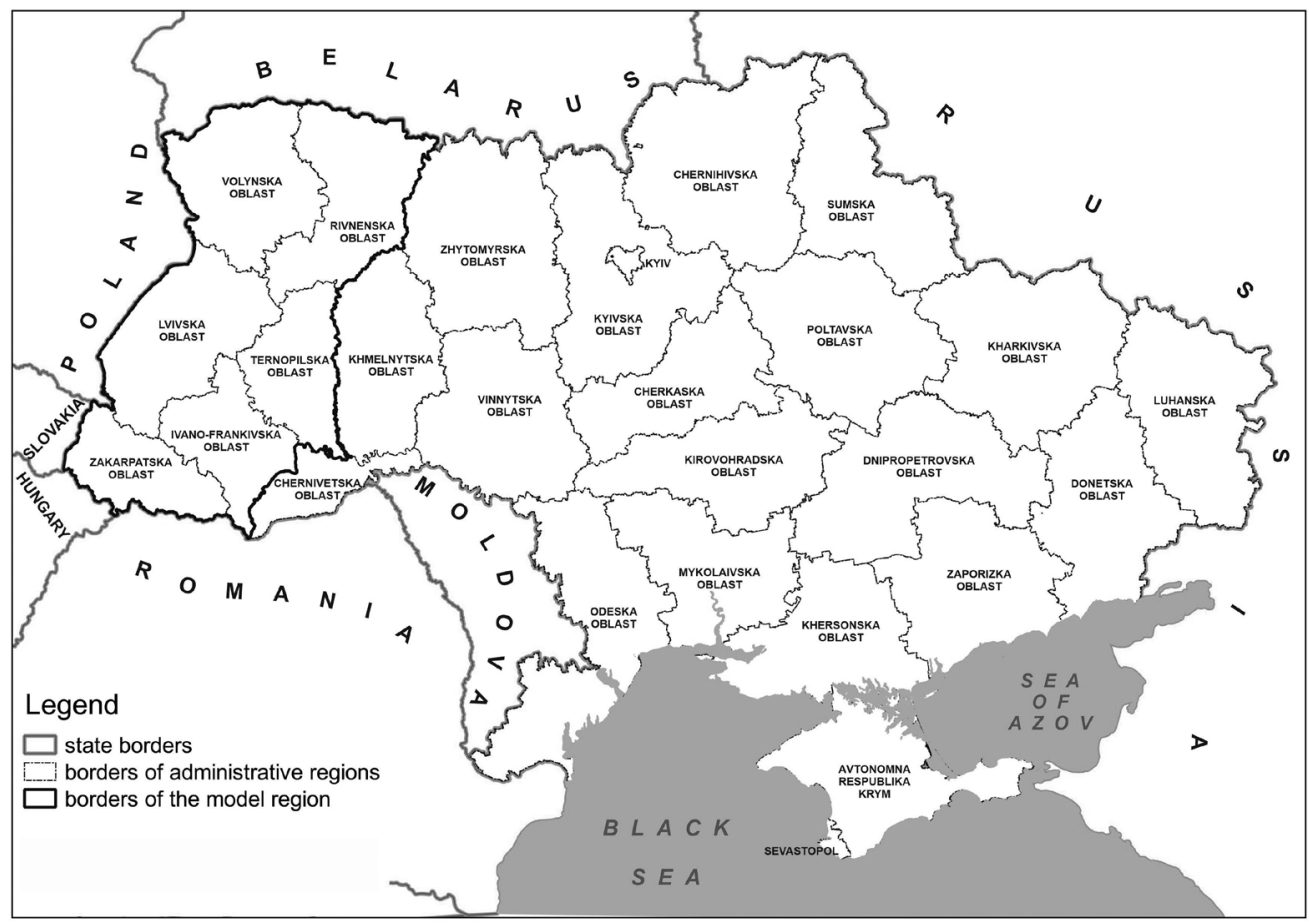

Figure 1. Ukraine and the model region

Given some gaps in the availability of statistical data, the main emphasis has been on case studies, content and SWOT analysis, with a search made for practices and typical patterns of perception that serve as markers revealing the dynamics of social space. The aim was for this to provide for identification of further scenarios, not only for cross-border cooperation or migration processes, but also for changes in the domestic political situation and geopolitical influences. 


\section{The origins of the economic condition and identity characterising regions in Ukraine at the beginning of the 21st century}

Ukraine resembles other countries in the way the historical factor has been exerting an extremely important influence on specifics of regional economic development, the current state of the regional economy, and features of regional population identity. In our opinion, the consequences of impacts on the current level of economic development, social sphere, interethnic and interfaith relations, and the choice of vector for the development of society have been neither assessed properly not studied sufficiently. This factor of course remains extremely important in shaping Ukraine's prospects for spatial development, as well as the prerequisites and opportunities associated with balanced development of Ukraine and its regions.

It should further be noted that regional features of economic development are less inert, while their past impact on migration, the demographic situation, ethnic composition, mentality, social development priorities, etc. are very long-lasting and determine the modern diverse and mosaiclike identity of the regions of Ukraine.

The routes taken by long-vanished borders crossing the territory of modern Ukraine may have their own phantom manifestations and influences on electoral processes, choice of priorities among parties and politicians, and perception or non-perception of integration processes, which have all found their clear confirmation in the modern history of the country. Thus, during most of its history (except for a few short periods) Ukraine did not enjoy statehood of its own, but was rather a part of different empires (the Polish-Lithuanian Commonwealth, the Russian or Austro-Hungarian Empires, the USSR). However, not unnaturally, it was the time within and status of being part of the USSR that did most to influence current features of regional development, with changes occurring in the borders of the then Ukrainian Soviet Socialist Republic (UkrSSR) as a part of the Soviet Empire and, finally as a consequence of what the communist regime sought to achieve, not least in its attempts to break resistance offered to violent collectivisation and other economic and social experiments (Vasiliev, 2005).

From the USSR, Ukraine in fact inherited an economy with a whole set of problems, including such aspects crucial in the field of regional development as:

- a high level of anthropogenic loading of the territory (not least in terms of environmental pollution);

- a deformed structure in which the share of nature-intensive industries is excessive;

- an uneven territorial distribution of production;

- a structure also inconsistent with regions' capabilities and features of potential where natural resources are concerned.

The country has also inherited a number of problems in the form of 'time bombs' relating to regional identity.

A special place among the regions of Ukraine on this list is occupied by Donbass (the Donetsk and Luhansk regions). The Kremlin's policy there led to significant reduction of the local Ukrainian population during the artificially-generated Holodomor (Great Famine) of the 1930s. The Ukrainians who died then were replaced by residents from other regions of the USSR (mostly the centre of Russia's European part), who were brought in en masse, settling mainly in cities - i.e. the industrial centres behind the foundation of heavy industry in the then Soviet Union (Zanuda \& Dorosh, 2015, June 2). 
The displaced population in question has historically perceived ethnically Ukrainian lands in the region solely through the prism of Soviet propaganda, to the point where identification of people as citizens of Ukraine was not achieved. After the collapse of the USSR, this factor became one of the main ones allowing Russian propaganda to successfully shape - within a majority in the local population - attitudes of negativity towards Ukrainian language and history, and in fact everything that had to do with Ukraine. The region's population was thus characterised primarily by a 'postSoviet' mentality sustaining illusory hopes that life would surely improve if only the territory were to return to Russia as the successor-state vis-à-vis the USSR. So it was that Russia managed to launch its 2014 aggression, thereby coming to occupy parts of both the Luhansk and Donetsk regions.

It was a to a far-greater degree that a population's national-identity issues came to be exploited by Russia in the case of Crimea, with the former proving able to occupy the latter peninsula entirely before the war in Donbass broke out.

Table 1. 1940-1956 growth in gross industrial output, by region

\begin{tabular}{|c|c|c|c|}
\hline Regions* & 1945 & 1950 & 1956 \\
\hline UkrSSR (total) & 26 & 115 & 246 \\
\hline Cherkasy & 23 & 90 & 199 \\
\hline Chernihiv & 21 & 86 & 162 \\
\hline Chernivtsi & 36 & 177 & 373 \\
\hline Crimean & 23 & 81 & 179 \\
\hline Dnepropetrovsk & 21 & 119 & 262 \\
\hline Drohobych & 72 & 200 & 430 \\
\hline Kharkiv & 25 & 111 & 255 \\
\hline Kherson & 22 & 92 & 264 \\
\hline Khmelnytsky & 32 & 95 & 195 \\
\hline Kirovograd & 16 & 64 & 153 \\
\hline Kyiv city & 24 & 136 & 365 \\
\hline Kyiv region & 31 & 96 & 180 \\
\hline Lviv & 52 & 341 & 900 \\
\hline Mykolayivska & 21 & 147 & 319 \\
\hline Odessa & 17 & 97 & 225 \\
\hline Poltava & 19 & 82 & 173 \\
\hline Rivne & 51 & 166 & 378 \\
\hline Stalin & 41 & 124 & 227 \\
\hline Stanislavska & 41 & 169 & 316 \\
\hline Sumy & 21 & 104 & 197 \\
\hline Ternopil & 36 & 110 & 246 \\
\hline Transcarpathian & - & 100 & 182 \\
\hline Vinnytsia & 26 & 101 & 194 \\
\hline Volyn & 32 & 132 & 340 \\
\hline Voroshilovgradskaya & 31 & 111 & 223 \\
\hline Zaporozhye & 16 & 93 & 251 \\
\hline Zhytomyr & 27 & 110 & 223 \\
\hline
\end{tabular}

* regions related to model macro-region in bold italics

Source: (Achievements (1957, p. 52). 
Statistics from official Soviet sources offer a quite clear demonstration of the Kremlin's efforts to pursue the destruction of Ukrainian identity in certain regions' populations, and in indeed Ukraine as a whole, not least through the planned implementation of new projects serving economic development. Statistics on certain aspects of regional development policy in Ukraine, enforced under instruction from Moscow, therefore prove quite interesting.

According to Achievements (1957, p. 52): 'A large number of light-manufacturing and foodindustry enterprises, construction materials industry enterprises and enterprises of other industries, working on the local raw materials, have been built in all oblasts (regions). A significant number of enterprises built in the former agricultural oblasts are not only of republican but also federal significance. Industry in the western regions develops especially rapidly after their reunification with the Ukrainian SSR. The total volume of industrial production in 1956 in the UkrSSR as a whole increased 2.5 times compared to 1940, and in the Volyn region - 3.4 times, in Drohobych - 4.3 times, in Lviv - 9 times. The city of Lviv has been transformed into a major industrial center, with significant importance in the UkrSSR economy.' (see Table 1).

Of course, we can assume that the outpacing speed of industrial development in the western regions of Ukraine was due solely to the desire to raise the living standards of the local population. However, in this, and especially in the Lviv example, we can see the Kremlin's desire to change the ethnic structure of the region's population by using newly-resettled workers and officials, managers and communist bureaucrats needed for the recently established factories. This policy was designed to change the local population's negative attitudes towards communist ideology and practice in the region. For instance, through to 1939 , a majority of Lviv inhabitants were Poles, Jews, and Ukrainians. However, as of 1951, almost 39\% of the Lviv population comprised Russians. In Kyiv, Chernihiv and Sumy, this percentage was much lower (Radiosvoboda, 2011).

However, unlike in Donbass, the scenario of Lviv being made over into a Russian-speaking failed completely (also unlike in the case of Riga, Latvia, where Latvians became a minority population as a result of Kremlin policy). For a majority of the Russian-speaking immigrants arriving into the region from Russia and other Soviet Republics achieved a status of patriot vis-à-vis Ukraine.

Further interesting data in the table concern the indicators characterising industrial development in Crimea. These are in fact significantly lower than the all-Union ones, formed on the basis of Russian SSR averages, with this pointing indirectly to the number and nature of problems as the peninsula was transferred to Ukraine, which invested huge sums in raising this region.

Furthermore, it was actually at the expense of Ukraine's natural, financial and human resources - which were all exploited - that the economy of the USSR's eastern regions enjoyed development (Encyclopedia, 1970).

The process by which home-grown professionals within Ukraine were replaced by newcomers lasted practically the entire postwar period, until the time the USSR collapsed. Notwithstanding that, as of the beginning of the period of Ukraine's independence, the vast majority of the country's population was ready to position itself as Ukrainian citizenry supporting the country's newfound status as independent (the December 1, 1991 Referendum). Despite all the interregional differences, and the specific role of Western regions, all the diversity of the population in the regions and the history of their entry and stay in Ukraine (UkrSSR), the citizens of the country displayed unanimity over the choice of an independent path of development. 


\section{Features of development in the border regions of Western Ukraine and main drivers of socio-economic change}

\section{Social transformations}

Traditionally, the western border regions of Ukraine (other than that of Lviv, whose reasons for advanced industrialisation have already been mentioned, and in part also Ivano-Frankivsk, as a centre of oil production historically) have not been among those most developed industrially. In 1990, the year before the proclamation of Ukraine's independence, the Transcarpathian region accounted for $0.89 \%$ of USSR industrial production, Volyn for $0.99 \%$, Ternopil for $0.86 \%$, Rivne for $1.79 \%$ and Ivano-Frankivsk for 1.96\% (Lisovsky, 2009).

The macro-region level of development of agriculture has typically also been lower than the Ukrainian average. All oblasts except Ternopil were characterised by relatively small shares of land in agricultural and arable use. In the mountainous areas of Western Ukraine the shortage of agricultural land was particularly noticeable, creating a labour-surplus problem. As a result, the male population traditionally transferred to eastern regions of Ukraine or to other Republics of the USSR in order to gain seasonal earnings. Once Ukraine's independence had been proclaimed, that experience proved useful, albeit with a change of direction of migration from east to west. The result has been a mass departure of residents of the macro-region with a view to money being earned in other European countries.

Although there are no accurate estimates of the number of migrant workers from Ukraine present elsewhere, and although the official statistics do not reflect the real decline in population that has occurred, the significance of migration-related phenomena for regions in western Ukraine may not be overlooked. This was long facilitated by push factors in the form of fairly high of unemployment and low wages, as well as a pull factor in terms of the growing demand for Ukrainian workers abroad. According to Lücke and Saha (2019), '69\% of the labour migrants, in the 2017 migration module of labor survey, were from the western Ukraine, although only $27 \%$ of the country's population lives in this macro-region. The much greater trend towards migration here is not a new phenomenon. The West remains a relatively poor macro-region, producing only $16 \%$ of Ukraine's GDP'.

Thus, even given the traditionally high birth rate and lack of official records about numbers of people leaving Ukraine, all western regions of the country reported a decrease in population compared with 1991. The magnitudes of this movement ranged from $1 \%$ in the Transcarpathian region to $9 \%$ and almost $12 \%$ in the Lviv and Ternopil regions respectively ${ }^{2}$. A slight increase (from several hundred to more than a thousand people) took place in 2014-2016 in the Volyn, Zakarpattia, Ivano-Frankivsk and Rivne regions, this being partly explicable in terms of resettlement from territories occupied temporarily by Russia, as well as the participation of migrant workers in military and political events. At the same time, where the Lviv and Volyn regions are treated as examples, the population decline over a ten-year period (2010-2020) is to be seen in most of the cities and towns (Fig. 2), except for the Lviv Metropolitan Area and border crossing-points.

Income from labour migration has come to represent a significant investment for private development, small business, education, and day-to-day spending. Also noticeable are rates of increase in income that are higher than average for Ukraine (Fig. 3).

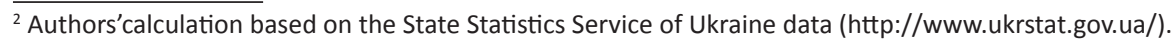




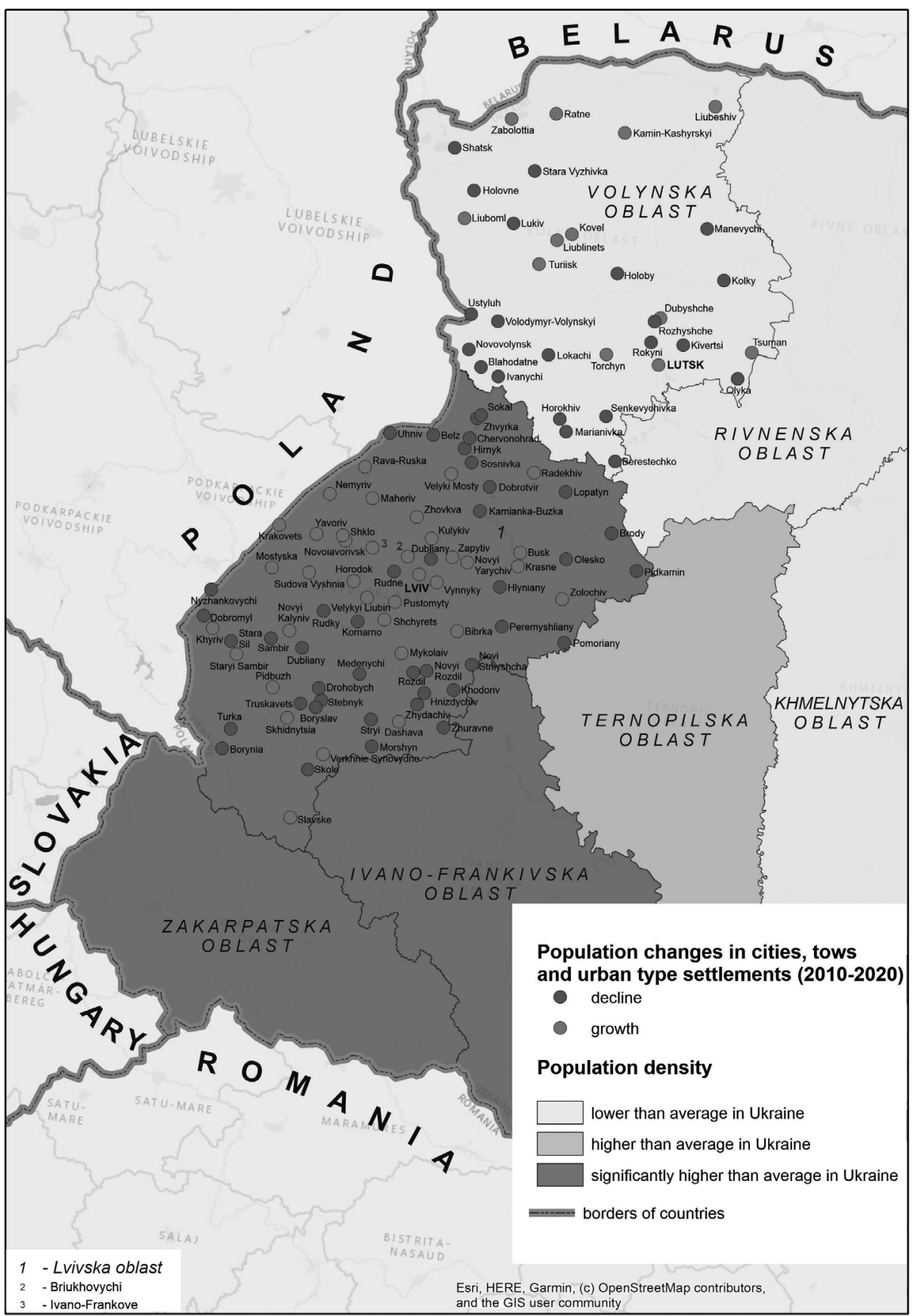

Figure 2. Population dynamics in cities and towns of Ukraine's Lviv and Volyn regions 


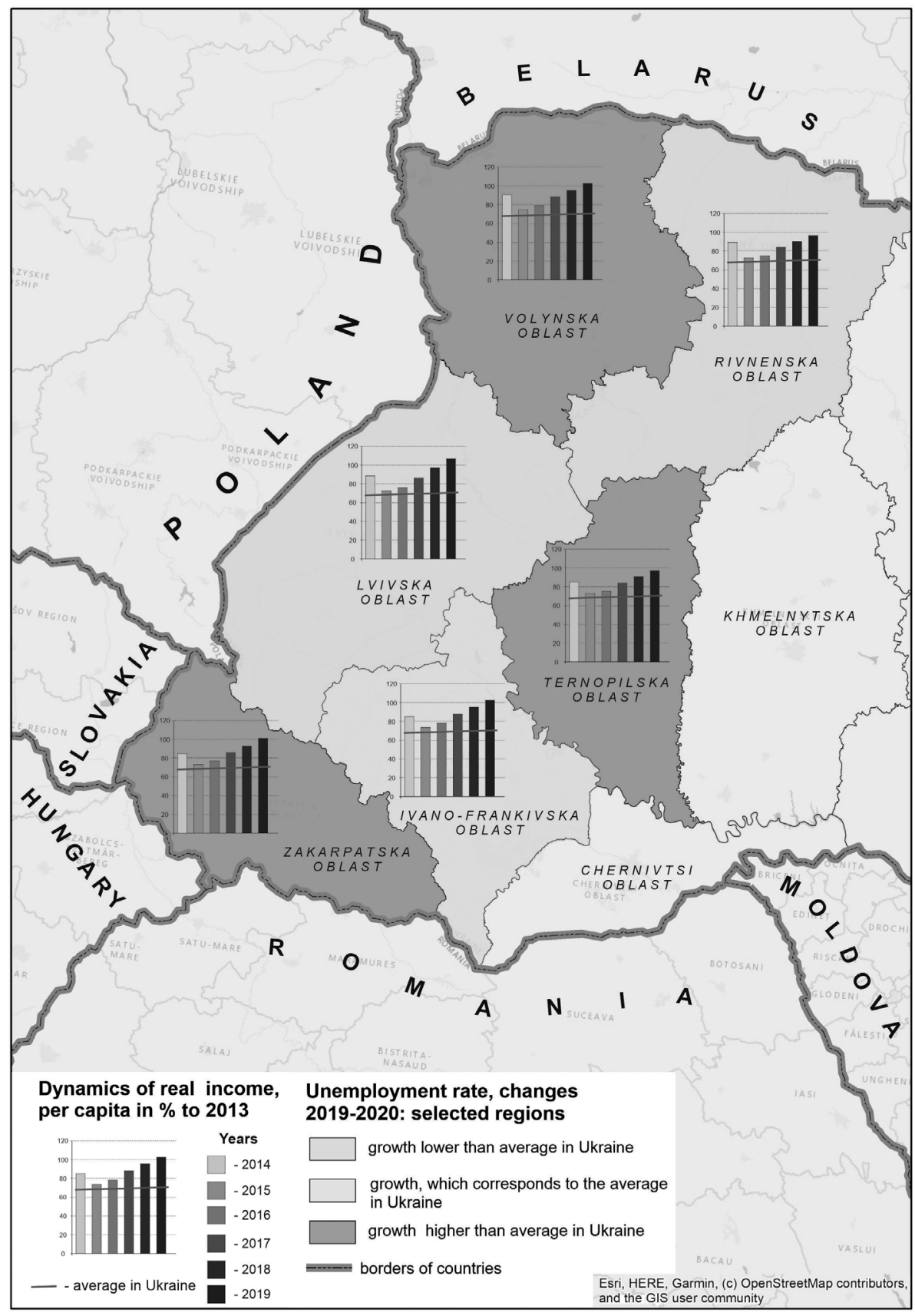

Figure 3. Income of the population in western regions of Ukraine 


\section{Typical patterns in social and electoral behaviour}

Differences in mentality, patterns of behaviour and priorities with the populations living in different regions are in fact noticeable in almost every country in the world, and all the more so in those with a long history of ethnic and, particularly, state territory formation). In Ukraine, whose territory only took shape as recently as in the mid-20th century (and with part of that anyway under Russian occupation for seven years now), such a difference between the populations inhabiting different regions is an objective reality.

The long periods over which significant parts of the territory on which the process of Ukrainian ethno-genesis began formed part of different states (i.e. the Polish-Lithuanian Commonwealth, Russia and Austria-Hungary, Romania, Czechoslovakia and, finally, the Soviet Union - as de facto a next model for Russian Empire) obviously combines with the factor of non-statehood (except in the era of Kievan Rus, the transient state under Bohdan Khmelnytsky and the Ukrainian National Republic) to affect significantly the ethno-social and ethno-political processes at work in their environment, with the result that special types of regional identity, regional stereotype, mentality and pattern made their appearance (Makarenko, 2018).

Accordingly, local populations have developed the skills they need to adapt to abrupt changes in social conditions and the ability to survive in the face of adverse external circumstances. However, to some extent this has taken place at the expense of reserve (suspicion) towards relationships with state institutions.

Unlike most other regions of Ukraine, the country's west spent less time under the influence of the Soviet Union, and this has been a factor encouraging the preservation of historical traditions, entrepreneurship and an ability to make independent decisions about economic activity. This despite all the large-scale deportations and even direct physical destruction of the population living locally.

Additionally, in contrast to Central and Eastern Ukraine - faced since the beginning of the 20th century with significant (conditionally voluntary and forced) migratory movements to the East (meaning Siberia, the Far East and Kazakhstan), the bulk of Western Ukrainian migrants moved west - to Canada, the USA, Brazil and Argentina. The rather powerful diaspora formed in those countries, has not lost its historical connection with the home country. Indeed, since the time Ukraine's independence was proclaimed, and during the Orange Revolution and Revolution of Dignity in particular, it made a significant impact shaping political choices made by the region's population, as well as their behavioural responses to central-government action.

Largely due to the above factors, the population in the western border regions manifests a greater degree of individualisation, rejection of government structures and a lesser reliance on the state when it comes to the addressing of personal needs, and so on. That is why the region's population contains a rather large share of people who focus on civic activity - $22 \%$, as compared with just $9.7 \%$ of the population in Eastern Ukraine (Reznik, 2019). The latter characteristic applies in particular to the regions immediately bordering Poland, i.e. those of Lviv and Volyn.

Thus, the western-border regions have also demonstrated specific electoral behaviour during all of the presidential elections that have taken place in Ukraine. The population here has traditionally supported presidential candidates taking (or proclaiming) a patriotic position when it comes to the protection of Ukraine's national interests and a pro-Western course for the country. This means simultaneously a distancing from Moscow. In several cases, voting followed a 'lesser of two evils' principle - the candidate then chosen being the one perceived as less (if only relatively less) pro-Russian and pro-communist. 
Thus, in 1991, the western regions cast the most votes for Vyacheslav Chornovil (a Ukrainian dissident convicted during the Soviet era) in his run against the former Communist Party leader Leonid Kravchuk (who nevertheless won). In the next elections - of 1994 - voters chose Kravchuk in first place, as they considered him a more acceptable candidate than the 'red director' Leonid Kuchma (who nevertheless won). In 1999, the same kind of scenario played out again, as the region voted for Kuchma to prevent a victory for the communist Symonenko (on this occasion the actual scenario that played out). In 2004, Viktor Yushchenko (leader of the Orange Revolution) won an unconditional victory in the western Oblasts ... and the election overall; while in 2010 Yulia Tymoshenko received the most votes in the West (even as Viktor Yanukovych won in Ukraine as a whole). In 2014, the election winner, Petro Poroshenko (with his strong pro-Ukrainian position) received his highest percentage of votes in Western Ukraine (Radiosvoboda, 2019). In the 2019 elections, the only region (other than a foreign constituency) in which Poroshenko prevailed over Volodymyr Zelensky (a technical candidate from an oligarchic group) was the Lviv region (Table 2).

Table 2. Results of voting in Ukraine's Presidential Elections of 2014 and 2019 (support for Poroshenko)

\begin{tabular}{|l|c|c|c|c|}
\hline \multirow{2}{*}{ Region } & \multicolumn{2}{|c|}{2014} & \multicolumn{2}{c|}{2019} \\
\cline { 2 - 5 } & Number of votes, persons & $\%$ & Number of votes, persons & $\%$ \\
\hline Volyn & 304931 & 69.92 & 166266 & 33.97 \\
\hline Transcarpathian & 301617 & 62.02 & 73223 & 16.69 \\
\hline Ivano-Frankivsk & 518506 & 65.13 & 267488 & 42.46 \\
\hline Lviv & 1079661 & 69.92 & 815966 & 62.79 \\
\hline Rivne & 341002 & 55.46 & 193301 & 37.49 \\
\hline Ternopil & 394207 & 60.63 & 242333 & 46.64 \\
\hline
\end{tabular}

Source: compiled by the authors on the basis of data from the Central Election Commission of Ukraine (CVK, 2014).

Beyond the obvious decline in support for Poroshenko, it is also possible to note certain peculiarities when it comes to voter participation in the region's elections. In Ukraine as a whole, the numbers voting in 2019 were higher by almost half a million people compared with 2014 . The numbers of voters in eastern and southern Ukraine increased markedly (partly due to the registration of migrants from occupied Donbas), only to declined quite a lot in the western Oblasts, and especially those of Lviv, Ivano-Frankivsk, and Ternopil Oblasts (where this state of affairs is accounted for by both political frustration and increased out-migration) (Fig. 4).

The choice can be illustrated by the opinion of an expert as regards the example provided by Transcarpathia (the region with the lowest turnout in 2019): 'against Poroshenko was the fact that in Transcarpathia, as well as in the whole of Ukraine, the popular opinion was that whatever is bad in the country is Poroshenko's fault. This is a purely populist mix of the president's authority, and a roll back to the thesis - "the Tsar is to blame for everything". That was the reason for voting for the "cat in the sack", who avoids any statements' (Ukrinform, 2019, April 5). 


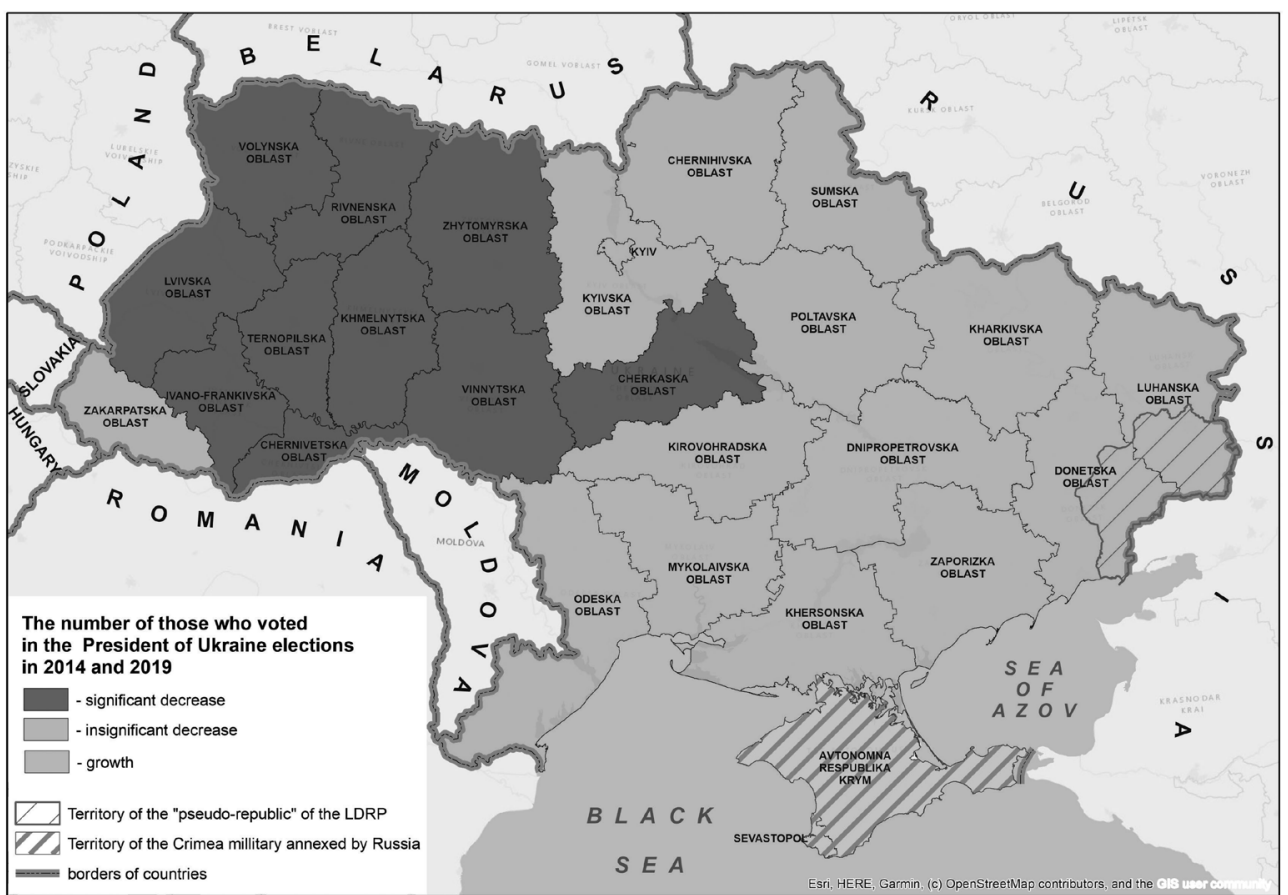

Figure 4. Changes in numbers of voters participating in the Presidential Elections of 2014 and 2019: regions of Ukraine

\section{Expectations and prerequisites for change in 2013-2014}

There is bound to be a controversial aspect to any overall assessment of the expectations of the population in the western border region, and their systemic nature and clarity. A number of factors both objective and subjective played a role in shaping those expectations, and as always in world history, the essence of these was reduced to a simple formula with a view to a dignified and happy life for oneself and one's descendants being assured (Table 3).

To a large extent, the public activity of the population in the western border regions arises out of its mass awareness of the conditions and living standards present in EU countries, including even those that are neighbours, let alone those further west. This level of activity was and clearly remains higher, and combines with the fact that the general economic situation in this region is better than that applying in the rest of Ukraine. After the rise in GDP growth in 2004-2007, and its sharp decline in 2009, there was de facto stagnation of the national economy in the years 2010$2013^{3}$, with Ukraine increasingly lagging behind its more successful western neighbours.

Residents of the western border regions could see all this during their forced economic shuttle flights and trips to work. In particular, year after year they were in a position to see how life in those neighbouring countries was improving, even as things in Ukraine continued to stagnate. In fact, however, the influence of the so-called 'showcase' effect was intensified. For the relatively short stays made in what had likewise been communist countries allowed visitors from the border

\footnotetext{
${ }^{3}$ Authors'calculation based on the State Statistics Service of Ukraine data (http://www.ukrstat.gov.ua/).
} 
regions to see many good things, without fully appreciating (or fully needing or wishing to appreciate) the complexity of the challenges already dealt with (gone through or even suffered) by those neighboring countries and their populations. They likewise fail to fully note the ongoing deep problems of inequality, still on the agenda for EU countries.

Table 3. Prerequisites for social transformations in 2013-2014: western regions of Ukraine

\begin{tabular}{|l|l|}
\hline \multicolumn{1}{|c|}{ Driving forces } & \multicolumn{1}{c|}{ Hidden conflicts } \\
\hline - An awareness of the high standard of living and \\
$\begin{array}{l}\text { standards in general present in EU countries. } \\
\text { - A striving for spatial justice (and the overcoming of } \\
\text { regional imbalances). }\end{array}$ & $\begin{array}{l}\text { Ignorance of the 'price' attached to the democracy } \\
\text { and economic development characteristic for the } \\
\text { EU (i.e. the duration and complexity of necessary } \\
\text { reforms) }\end{array}$ \\
$\begin{array}{l}\text { A collective memory of persecution and repression } \\
\text { in the USSR context, underlying the desire for a } \\
\text { different civilisational choice. }\end{array}$ & $\begin{array}{l}\text { Unwillingness to commence with change at the } \\
\text { level of the individual (by ceasing with illegal } \\
\text { - } \begin{array}{l}\text { Hopes as regards the revival of linguistic and paying taxes, etc.) } \\
\text { cultural space. }\end{array}\end{array}$ \\
\hline
\end{tabular}

Source: author's own elaboration.

The inevitable results of this process were inflated expectations as to the quick fix to all socio-economic problems that European integration might offer. In addition, there was a lack of understanding that positive progress in improving living standards, socio-economic standards and comfort could only be achieved by balancing the mutual rights and responsibilities of citizens and the state (with taxes paid, smuggling stopped, and so on).

Where the measuring of identity was concerned, the possibility of European integration was seen as a decisive step in returning Ukraine to the family of European nations. It was the residents of the western border regions who perceived the Maidan events as the Revolution of Dignity. In the Western region, an absolute majority $-70.5 \%$ as of 2014 - defined Euromaidan as a conscious struggle for their rights on the part of citizens. This was the highest figure to be noted anywhere in Ukraine (DIF, 2014, November 19).

In particular, a poll of Maidan participants gave the activists from the western border regions the chance to offer the following assessments of the actions of the authorities that had provoked the action:

- 'This is such indignation, defending one's dignity. They were told one thing and then do another. And here they beat! ... And national as well, but also human dignity and values' (Stryi),

- 'There is a strong, deep, universal rise. Affected the basic values - life, death, future of children' (Lviv) (Reznik, 2019, p. 206).

Maidan in the eyes of participants from the western border regions was a manifestation of high public spirit:

- 'This is the desire for justice, courage, bravery! Where people seek justice, the Holy Spirit works. People are looking for the truth, they want the truth - they are tired of lies. I think this is a special moment. Not only in history, but also in the spiritual development of the people' (Stryi).

- 'The people are finally learning to react normally. Because it seems that they make it anyway, but he doesn't react. How much longer can you tolerate? The people are injured because they are post-Soviet. And now he realized that he needed to be cured' (Lviv) (Reznik, 2019, p. 207).

Thus, the residents of the western border regions had extremely high expectations for the outcome of a victory out of Maidan, and thus made a significant contribution to that victory. At the same time, the price to be paid for deep socio-economic transformations in the post-revolutionary period was not understood sufficiently. 


\section{Reflection of state policy issues on society in the border regions during the 2014-2019 period}

Thus participation in the Revolution of Dignity and the subsequent reset of government engendered hope for significant improvements in quality of life in most regions of Ukraine. This was largely a matter of the observance of human rights, the fight against corruption in public offices, social and spatial justice and, of course, a clear prioritisation of the European vector of integration.

Given that residents of the western regions were the most active participants at Maidan (7\% in Kyiv directly, $26.2 \%$ in other cities, $29.5 \%$ supported the protesters with food and money), this is exactly where such expectations were the highest, sometimes even radical (DIF, 2014, November 19).

At the same time, given the economic and geopolitical realities, expectations of this type could only be met partially, and rather slowly, with the result that public discontent and disillusionment grew. It should further be noted how, despite a generally higher level of national consciousness in the population of the western regions, there was no full success there (just as in other regions), when it came to efforts to evade media manipulation and the obvious dominance of the economy over ideology.

Table 4. State policy priorities: perception and implementation gaps

\begin{tabular}{|c|c|c|c|}
\hline $\begin{array}{l}\text { Declared priority of the } \\
\text { state policy }\end{array}$ & $\begin{array}{l}\text { Implementation } \\
\text { confirmation }\end{array}$ & Gaps and weaknesses & Perception by population \\
\hline $\begin{array}{l}\text { ‘New way of life’’1 } \\
\text { Eurointegration }\end{array}$ & $\begin{array}{l}\text { Association Agreement } \\
\text { with the EU, visa-free } \\
\text { regime, harmonisation of } \\
\text { legislation }\end{array}$ & $\begin{array}{c}\text { Different pace and } \\
\text { success of reforms in } \\
\text { different industries, such } \\
\text { as medical. }\end{array}$ & $\begin{array}{l}\text { Positive, mostly - as a } \\
\text { result of Maidan, rather } \\
\text { than political work }\end{array}$ \\
\hline $\begin{array}{l}\text { 'Live honestly!' Fight } \\
\text { corruption }\end{array}$ & $\begin{array}{l}\text { Creation of anti- } \\
\text { corruption institutions, } \\
\text { judicial reform }\end{array}$ & $\begin{array}{c}\text { Inefficiency of the bodies } \\
\text { set up (Golubo, 2019, } \\
\text { March 15) }\end{array}$ & $\begin{array}{c}\text { Changes not noticeable at } \\
\text { the local level }\end{array}$ \\
\hline 'Well-off life' & $\begin{array}{l}\text { Development of foreign } \\
\text { trade with EU countries. } \\
\text { A rise up the 'Doing } \\
\text { business' ranking ( } 41 \\
\text { points in } 5 \text { years). A } \\
\text { raising of the minimum } \\
\text { wage }\end{array}$ & $\begin{array}{l}\text { Rapid decline and slow } \\
\text { recovery of GDP and } \\
\text { income, a high degree } \\
\text { of devaluation of the } \\
\text { hryvnia. Dialogue over } \\
\text { small-business issues. }\end{array}$ & $\begin{array}{c}\text { 'Tax Maidan', } \\
\text { dissatisfaction with } \\
\text { quality of life, migration } \\
\text { abroad, a growing sense } \\
\text { of social injustice. }\end{array}$ \\
\hline $\begin{array}{c}\text { 'Live free!' } \\
\text { Decentralisation of } \\
\text { power }\end{array}$ & $\begin{array}{l}\text { Launch of decentralisation } \\
\text { reform in } 2014 . \\
\text { Completed establishment } \\
\text { of community units of } \\
\text { administration in } 2020 \text { by } \\
\text { the new government. }\end{array}$ & $\begin{array}{c}\text { Presence of a certain } \\
\text { element of coercion, } \\
\text { formation of communities } \\
\text { with quite disparate levels } \\
\text { of territorial capital }\end{array}$ & $\begin{array}{l}\text { Mostly positive, but } \\
\text { depending on the } \\
\text { capacities of the } \\
\text { communities established }\end{array}$ \\
\hline $\begin{array}{c}\text { 'Live safely!' Defense, } \\
\text { territorial integrity, } \\
\text { protection against } \\
\text { violence }\end{array}$ & $\begin{array}{l}\text { Restraint of Russian } \\
\text { aggression. A radical } \\
\text { reform and strengthening } \\
\text { of the Army and Police. } \\
\text { Establishment of a } \\
\text { political dialogue with } \\
\text { leaders of key countries in } \\
\text { the world. }\end{array}$ & $\begin{array}{l}\text { Unfulfilled election pledge } \\
\text { 'to stop the war' (at that } \\
\text { time - 'anti-terrorist } \\
\text { operation' - in eastern } \\
\text { Ukraine). }\end{array}$ & $\begin{array}{l}\text { Risks of conscription, } \\
\text { weak understanding of } \\
\text { the essence and value of } \\
\text { effective foreign policy. }\end{array}$ \\
\hline
\end{tabular}

Source: authors' own elaboration. 
It is worth taking a closer look at state policy priorities (especially those of the fifth President), as well as their results, and their acceptance by the Ukrainian population (Table 4).

Obviously, or paradoxically, depending on the point of view, certain of the negative reactions were even more acute in the western regions than in Ukraine as a whole, to the extent that visa-free status with the EU as backed by falling incomes in the years 2014-2016 served to intensify labour migration. In addition, certain reform attempts went against the interests of local residents; initiatives to reform customs, tougher regulation of the small businesses tending to evade the required (level of) taxation, etc.

The issues of the military-service draft, the running of small businesses and the so-called 'Europlates $^{4}$ have also become negativity triggers in the border regions. Thus, despite the relatively high proportion of volunteers as of 2014, subsequent years brought a phenomenon of mass evasion of conscription (Korrespondent, 2015, January 15) - men from the western regions elect to travel abroad 'to avoid compulsory army service' (Stadnyk, 2015). Among the western regions, it was the Zakarpattia region that faced the worst problems, its young men even heading for Russia in order to evade mobilisation. This can be explained by the echo of Illovaisk tragedy of 2014, doubts about the competence of military leadership, and striking social contrasts, such as de facto nob-conscription of displaced persons, the children of influential people and relatively wealthy entrepreneurs. The lifestyle of the rest of the population, especially in large cities, which still provided for the food and entertainment industry was also a subject of matter. At the same time, the western regions had to adapt to several waves of migrants from Crimea and Donbas, whose integration into society proceeded disparately.

It is possible to illustrate the attitude of the inhabitants from certain regions to certain problems using the example of individual perception (Table 5).

Table 5. Western regions of Ukraine: the personal dimension of policy

\begin{tabular}{|c|c|c|}
\hline $\begin{array}{c}\text { 'He will not go to the army... I do } \\
\text { not believe that the authorities } \\
\text { will carry out this mobilisation in } \\
\text { a civilised manner', 'The West is } \\
\text { not ready to fight' - Lviv (Stadnyk, } \\
\text { 2015) }\end{array}$ & $\begin{array}{l}\text { Traffic jams, fights and indignation: } \\
\text { the results of several days of the } \\
\text { 'Euro-platers' protests - 'The first } \\
\text { day of the protest in Rivne region } \\
\text { ended in a fight' (Gerasimov, } \\
\text { Miroshnichenko \& Pasak, 2018, } \\
\text { November 21) }\end{array}$ & $\begin{array}{c}\text { In Krasny Pole near the city of } \\
\text { Khust in Transcarpathia, during } \\
\text { the visit of President Petro } \\
\text { Poroshenko, a participant of } \\
\text { the rally shouted several times } \\
\text { 'Thank you for poverty, Petro } \\
\text { Oleksiyovych!' (24tv, 2019, March } \\
16)\end{array}$ \\
\hline $\begin{array}{c}\text { Volynians against the 'Varyag' } \\
\text { from Donbass (Sadetska, 2019, } \\
\text { October 31) } \\
\text { Two deputy heads of the Volyn } \\
\text { Customs of the State Fiscal Service } \\
\text { have been suspended due to the } \\
\text { amber-smuggling scandal } \\
\text { (Ukrinform, 2016, March 25) }\end{array}$ & $\begin{array}{l}\text { Teachers of Ternopil region joined } \\
\text { a picket. (PON, 2014, December 8) }\end{array}$ & $\begin{array}{c}\text { In Ivano-Frankivsk region, villagers } \\
\text { are outraged by the restriction of } \\
\text { their right to establish Territorial } \\
\text { Communities. (Kostinyuk,2020, } \\
\text { January 28) }\end{array}$ \\
\hline
\end{tabular}

Source: authors' own elaboration.

While actual tangible protests against the President and governmental institutions were not frequent in the western regions, the decline in the level of support was accompanied by increased emigration sentiment, vulnerability to media manipulation (in the West in 2015-2016, only a year

\footnotetext{
${ }^{4}$ Europlate is a used car with a European license plate, which according to the documents is temporarily imported into Ukraine by a foreigner, but is in fact the unregistered property of Ukrainian citizens, imported without payment of customs duties for personal use, resale, etc.
} 
after the election, just $15.8 \%$ of respondents trusted the President, the mass media - 39.3\%) (KIIS, 2017), aggravation of the feeling of discrimination in the state, which was won historically and in 2013-2014, cases of subjective and objective confidence in the loss of income, and limited opportunities to obtain it in Ukraine.

It is worth mentioning that there were also conflicts brought about by the introduction of the language law in Ukraine (in particular as regards compulsory secondary education in Ukrainian). The manifestation of this was particularly acute in the areas of Hungarian minority residence in the Transcarpathian region.

\section{The pandemic crisis and its first consequences}

Given an anyway rather problematic economic situation resulting from the 2014 crisis, the effects of the COVID-19 pandemic have been particularly pronounced in the western regions. It is worth highlighting such aspects as:

- the rapid spread of COVID-19 in almost all border regions (as of early 2021, Chernivtsi region was the leader in the number of cases per 1000 people, while Volyn, Rivne, Ivano-Frankivsk and Ternopil were all in the top 10). Lviv and Zakarpattia regions joined them after a certain time-lag; - the restriction of labour migration in the spring of 2020 (as lifted gradually later), and the consequences of quarantine for small businesses as a significant factor in maintaining the welfare of the population;

- the closure or suspension of small businesses (not only hotels and restaurants, but also small shops, family bakeries, salons, etc.) has led to rising unemployment, numerous histories of bankruptcies or 'shadow' economic activity and social instability.

Doubts about the effectiveness of government efforts to overcome the problem have led, not only to increased nihilism, but also to certain protest attitudes even among the regional authorities. One example was the city of Ternopil, whose Mayor officially denounced and refused to observe the January 2021 quarantine (NUS, 2021, January 7). A similar decision was made earlier, in the summer of 2020, when the region was declared a so-called 'Red Zone' ('Such a blockade was in the days of the Tatars') (Ukrainian Pravda, 2020, August 3). In Ternopil, one of the markers of dissatisfaction with regional inequality was voiced - 'The "velour" restaurants ${ }^{5}$ are open in Kyiv, but here there is a transport blockade' (Ukrainian Pravda, 2020, August 5).

Therefore, despite the rather high level of support for the government elected in 2019, as of November 2020 , about $28 \%$ of polled respondents in Ukraine would be ready to join protests, with the highest readiness to do this being observed in the West (where the figure was 30\%), where the distrust rating has increased significantly (Ukrinform, 2021, February 5).

\section{Territories' development planning and cross-border cooperation}

Mechanisms to suspend external migration, as well as resist other negative socio-economic phenomena should be laid out as modern planning documentation is developed. This in particular means strategies for the socio-economic development of regions and communities, as well as macro-regional and cross-border programmes.

At the same time, it is also worth reviewing and analysing certain features of social space in the regions which serve to point to both high potential and obvious threats to development in the near future (Table 6).

\footnotetext{
${ }^{5}$ Restaurant owned by a Member of the 'Servant of the People' Party.
} 
Table 6. SWOT analysis for social space in the western border regions

\begin{tabular}{|c|c|}
\hline Strengths & Weaknesses \\
\hline $\begin{array}{l}\text { - High level of national consciousness } \\
\text { - Support for European integration } \\
\text { - Historical ties with EU countries } \\
\text { - Mobility and entrepreneurship } \\
\text { - A quite-high level of proficiency in the language of } \\
\text { neighbouring EU countries } \\
\text { - High adaptability to social and economic challenges, } \\
\text { readiness to retrain and master new professional skills }\end{array}$ & $\begin{array}{l}\text { - An understanding of the 'injustice' of the socio- } \\
\text { economic space in the state } \\
\text { - An unwillingness of a significant part of the } \\
\text { population to wait longer for the results of reform } \\
\text { - A prevalence of untaxed income received both in the } \\
\text { course of private entrepreneurship (with mini-hotels, } \\
\text { wineries, transport services, etc.) and activities carried } \\
\text { out in violation of the law (primarily in violation of } \\
\text { border controls) }\end{array}$ \\
\hline Opportunities & Threats \\
\hline $\begin{array}{l}\text { - Further support for cross-border cooperation, } \\
\text { introduction of appropriate standards, job creation } \\
\text { - State support for the return of migrants (prevention } \\
\text { of permanent departures) in the context of certain } \\
\text { trends in the EU economy } \\
\text { - Development of the tourism industry, creation } \\
\text { of new jobs, improvements in infrastructure in the } \\
\text { regions, using investments from migrant workers } \\
\text { returning from abroad }\end{array}$ & $\begin{array}{l}\text { - Growing distrust in the central government } \\
\text { - Acceleration of migration processes } \\
\text { - The loss abroad of the most-qualified and active } \\
\text { sector of labour resources } \\
\text { - The growing share of the population that is non- } \\
\text { working } \\
\text { - Geopolitical influences aggravating ethnic and } \\
\text { interfaith relations }\end{array}$ \\
\hline
\end{tabular}

Source: authors' own elaboration.

Unfortunately, attention to functional territories and macro-regions (as well as reform in the field of spatial planning in general) has only recently become part of Ukrainian government policy. In 2019, a Concept for the Development of the Ukrainian Carpathian Mountain Territories was adopted, and later - a State Programme for the Development of the Ukrainian Carpathians in 2020-2022, which deals with the development of the Transcarpathian, Ivano-Frankivsk, Lviv and Chernivtsi regions and is directed at the creation of a competitive economy, the building of a spatially-balanced road, production and social-infrastructure network, with development of tourist potential and the security of territories provided for.

In the past, cross-border cooperation programmes also were implemented in the Western macro-region - a State Programme for the Development of Cross-Border Cooperation during 20162020 and a Poland-Belarus-Ukraine Cross-Border Cooperation Programme under the European Neighborhood Instrument (2004-2006; 2007-2013; 2014-2020). Despite the certainly declarative nature of the State Programme and issues with funds appropriation, as well as the implementation of the trilateral cooperation programmes (an insufficient institutional base, limited awareness among Ukrainian beneficiaries, etc.), those documents laid the groundwork for further action aimed at both integration and the preservation of human potential.

The main documents which define goals and objectives for border-region development in the near future are the corresponding Development Strategies for the period 2021-2027.

We may thus speak of a pronounced vector of cross-border cooperation, which provides hope for the preservation of human capital as well as natural and cultural heritage, and for significant improvements in infrastructure. However, the prospects for the 'localisation and individualisation' of such projects' benefits (and hence for their positive perception by the local population) remain uncertain, notwithstanding ongoing processes of decentralisation.

In these, considerable attention is paid to the development of cross-border cooperation (Table 7). 
Table 7. Potential of cross-border cooperation in regional strategies

\begin{tabular}{|l|l|}
\hline \multicolumn{1}{|c|}{ Region } & \multicolumn{1}{c|}{ Emphasis in the Cross-Border Cooperation Strategy } \\
\hline $\begin{array}{l}\text { Volyn region } \\
\text { (VRSA, 2020) }\end{array}$ & $\begin{array}{l}\text { Strategic goal 4 'Development of cross-border cooperation'. Particularly infrastructural } \\
\text { support of cross-border cooperation and stimulation of regional cross-border } \\
\text { cooperation through support for economic, social and ecological initiatives. }\end{array}$ \\
\hline $\begin{array}{l}\text { Transcarpatian region } \\
\text { (MCTD, 2019) }\end{array}$ & $\begin{array}{l}\text { Renovation of the region (within one of the strategic goals) as a new creative centre } \\
\text { of international, interregional and interethnic multi-sectoral cooperation of the } \\
\text { Carpathian (South-Eastern) megaregion of Europe in existing and new formats } \\
\text { 'Visegrad +', Carpathian Convention, Carpathian Eurogion, etc. } \\
\text { Tasks to develop transport and logistics-related border infrastructure. }\end{array}$ \\
\hline $\begin{array}{l}\text { Lviv region } \\
\text { (LRSA, 2020) }\end{array}$ & $\begin{array}{l}\text { Participation in Euroregions (Carpathian and Bug). } \\
\text { Development of cross-border cooperation networks. } \\
\text { Strategic goal of 'Sustainable Spatial Development' that provides for the development } \\
\text { of cross-border infrastructure and the implementation of major infrastructure projects. }\end{array}$ \\
\hline
\end{tabular}

\section{Conclusions}

Today, Ukraine's western border regions are extremely important to the preservation of the identity and restoration of the territorial integrity of the country. Less affected by the 'corrosion' induced by Soviet slogans and stereotypes, the inhabitants of the regions in question not only played a key role in the events of the two revolutions aimed at democratising Ukrainian society, but also contributed to the spread of state unity in the central, eastern, and southern regions. In addition, they remain rebroadcasters of European values and innovations, both in formal programmes and at the level of personal interactions.

At the same time, the electoral choice made in favor of obscure political manipulation in 2019 pointed to the existence of certain gaps as regards the full use of the western border regions' potential in the process of European integration. On the one hand, such a reaction reflects the lack of significant changes in social justice (in the institutional, economic and cultural dimensions), as well as insufficient communication with government agencies. On the other hand, the individualism and historically inherent distrust in central government within the region's society have led to a resistance to change at the level of the self-awareness of the local population. Shifts towards democratic society and the introduction of European mechanisms thus need to be accompanied by the de-shadowing of entrepreneurship, as well as by a willingness to wait longer for the positive results of reform and to participate in the steering of their implementation at local level.

Today we can point out the second, post-2014, wave of distrust in the chosen political force, as unfortunately exacerbated markedly by consequences of the COVID-19 pandemic. The lack of an adequate government-response strategy (reasonable timelines and quarantine measures, adequate medical care, a well-thought-out vaccination campaign and measures to support the most vulnerable social groups and businesses, etc.) has certainly affected all Ukraine's regions. At the same time, it was in the western Oblasts, where tourism, the hotel and restaurant business, brokerage and retail trade all play a significant role that the situation emerged as much worse, given certain barriers to temporary labour migration. Therefore, given also rising unemployment and numerous stories of complete losses of livelihood, it was possible to anticipate a yet-further increased outflow of labour, which will only increase with so-called educational migrations (as students will not return to Ukraine having received an education and socialisation in the EU). The 
unpredictability of outcome of the next Parliamentary and Presidential Elections may present an additional challenge, where, in addition to the desired return of pro-European and pro-Ukrainian forces, a pro-Russian revenge may take place, explicitly, or through being camouflaged as another political technology.

Intensification of cross-border cooperation (de facto as opposed to de jure) is a key tool in any revival of border regions and preservation of their human capital, and this is important for Ukraine and for European partners alike. Support for legal small businesses, improved logistics, the introduction of training and educational programmes and social communication will all be of special value in this respect. However, the ability of the Ukrainian side to actually take such action remains in question.

\section{References}

24tv (2019, March 16). Poroshenko thanked for poverty in Transcarpathia. 24 Channel. Retrieved from https://24tv.ua/ru/poroshenko_poblagodarili_za_bednost_na_zakarpate_n1127463

Achievements (1957). Achievements of Soviet Ukraine in forty years. Kyiv: State Statistical Publishing House.

Adams, P. C. (1995). A reconsideration of personal boundaries in space-time. Annals of the Association of American Geographers, 85(2), 267-285. https://doi.org/10.1111/j.1467-8306.1995.tb01794.x

Caldo, C. (1996). Geografia Umana. Florence: Palumbo.

Capello, R. (2019). Interpreting and understanding territorial identity. Regional Science. Policy \& Practice, 11(1), 141-158. https://doi.org/10.1111/rsp3.12166

CVK (2014). Elections of the President of Ukraine 2014. CVK. Retrieved from https://www.cvk.gov.ua/ pls/vp2014/wp001

DIF (2014, November 19). Maidan Anniversary - public and expert opinion poll. Round Table. Ilko Kucheriv Democratic Initiatives Foundation. Retrieved from https://dif.org.ua/article/richnitsyamaydanu-opituvannya-gromadskoi-ta-ekspertnoi-dumki

Encyclopedia (1970). Encyclopedia of the national economy of the Ukrainian SSR (vol. 2). Kyiv: Main Edition of the Ukrainian Soviet Encyclopedia.

Forer, P. (1974). Space through time: a case study with NZ airlines. In E. L., Cripps (Ed.). Space-time Concepts in Urban and Regional Models (pp. 22-45). London: Pion.

Fukuyama, F. (2013). What Is Governance? CGD Working Paper, 314. Washington, DC: Center for Global Development. Retrieved from http://www.cgdev.org/content/publications/detail/1426906

Gerasimov, I., Miroshnichenko, A., \& Pasak, A. (2018, November 21). Congestion, fights and indignation: the final plot of several days of protests of "Euro-blasphemers". Channel 5. Retrieved from https:// www.5.ua/suspilstvo/zatory-biiky-ta-oburennia-pidsumkovyi-siuzhet-kilkadennykh-protestivievrobliakheriv-181614.html

Golubo, A. (2019, March 15). Lost time. Fight against corruption under President Poroshenko. Deutsche Welle.

Harvey, D. (2006). Spaces of Global Capitalism: Toward a Theory of Uneven Geographical Development. London, New York, NY: Verso.

Huntington, S. (1993). The Clash of Civilizations? Foreign Affairs, 72(3), 22-49 https://doi. org/10.2307/20045621

IDSR (2018). Ukrainian society: migration dimension: national report. Kyiv: Institute of Demography and Social Research named after M. V. Ptucha of the National Academy of Sciences of Ukraine. Retrieved from https://www.idss.org.ua/arhiv/Ukraine_migration.pdf

Janelle, D. G. (2001). Time-Space in Geography. International Encyclopedia of the Social \& Behavioral Sciences (pp. 15747).

Kjar, A. M. (2004). Governance. Cambridge: Polity Press. 
Kolosov, V. A., \& Vendina, O. I. (2011). Russian-Ukrainian border: twenty years of divided unity. Moscow: New chronograph.

Korrespondent (2015, January 15). Mobilization abroad. How Ukrainians are fleeing the army. Korrespondent. Retrieved from https://ua.korrespondent.net/ukraine/politics/3472256-mobilizatsiia-zakordon-yak-ukraintsi-tikauit-vid-armii

Kostinyuk, O. (2020, January 28). In Ivano-Frankivsk region, peasants are outraged by the restriction of their right to establish OTGs. Golos Ukrainy. Retrieved from http://www.golos.com.ua/ article/326924

Kostyuk, S. (2004). Euroregions in the Ukrainian border regions - unrealized potential of Ukraine-EU relations. Man and politics, 3, 21-28.

Lefebvre, H. (1991). The Production of Space. Malden, MA: Blackwell Publishing.

Lisovsky, S. A. (2009). Society and nature: balance of interests in the territory of Ukraine. Kyiv: Institute of Geography of the National Academy of Sciences of Ukraine.

LRSA (2019). Strategy of Development of the Lviv region for the period 2021-2027. Lviv Regional State Administration. Retrieved from https://loda.gov.ua/upload/users_files/22/upload/948_Strategija.pdf

Lücke, M., \& Saha, D. (2019). Labour migration from Ukraine: Changing destinations, growing macroeconomic impact. German Advisory Group. Berlin: Berlin Economics. Retrieved from https:// www.german-economic-team.com/ukraine/en/policy-study-02-2019-2/

Makarenko, N., (2018). Features of formation and influence of regional identities on political process in Ukraine. IF Kuras NAS of Ukraine, 44, 190-200.

Maksymenko, S., Kish, E., Lendiel, M., \& Studennikov. I. (2000). Regional policy in European countries. Lessons for Ukraine: the project of the Kyiv Center of the East-West Institute. Kyiv: Logos.

MCTD (2019). Regional Strategy of Development of the Transcarpathian region for the period 2021-2027. Ministry for Communities and Territories Development. Retrieved from https://www.minregion.gov. ua/napryamki-diyalnosti/derzhavna-rehional-na-polityka/strategichne-planuvannya-regionalnogorozvitku/regionalni-strategiyi-rozvytku-na-period-do-2027-roku/regionalna-strategiya-rozvytkuzakarpatskoyi-oblasti-na-period-2021-2027-rokiv/

Mikula, N. A. (2004). Inter-territorial and cross-border cooperation. Lviv: IRD NAS of Ukraine.

NUS (2021, January 7). Ternopil again went against the government's decision - no quarantine is planned from January 8. New Ukrainian School. Retrieved from https://nus.org.ua/news/ternopilznovu-pishov-proty-rishennya-uryadu-ne-planuyut-karantyn-iz-8-sichnya/

Perkmann, M. (2003). Cross-border Regions in Europe: Significance and Drivers of Regional Crossborder Cooperation. European Urban and Regional Studies, 10(2), 153-171. https://doi. org/10.1177/0969776403010002004

Pierre, J., \& Peters, B. G. (2000). Governance, Politics and the State. Basingstoke: Macmillan Press.

Pirozhkov, S. (Ed.) (2002). Migration and border regime: Belarus, Moldova, Russia and Ukraine. Kyiv: Center for Problems of Forced Migration in the CIS and the National Institute for International Security.

Podgrushny, G. P. (Ed.) (2010). Problems of social geography. Border areas: methodological approaches and research experience. Kyiv: Institute of Geography of the National Academy of Sciences of Ukraine.

PON (2014, December 8). Teachers of Ternopil region went on a picket. PON. Retrieved from https://pon. org.ua/news_regions/3658-vchiteli-ternopilshhini-vijshli-na-piket.html

Popkova, L. I. (2005). Geography of the population of the Russian-Ukrainian border. Smolensk: Universe. Radiosvoboda (2011). Russians in Lviv: Patriots of Ukraine or the "Fifth Column"? Radiosvoboda.

Radiosvoboda (2019). How Ukrainians vote. Seven cards explaining the presidential election. Radiosvoboda.

Reznik, O. (Ed.) (2019). Sociological dimensions of civil society in Ukraine. Kyiv: Institute of Sociology of the National Academy of Sciences of Ukraine.

Rose, G. (1995). Place and identity: A Sense of Place. In D., Massey \& P., Jess (Eds.). A place in the world: Places, cultures and globalization (pp. 87-132). Oxford: Oxford University Press.

Sadetska, A. (2019, October 31). Volyn against "Varyag" from Donbass. Volyn. Retrieved from https:// www.volyn.com.ua/news/139018-volyniany-proty-variaha-z-donbasu 
Stadnyk, H. (2015). More and more Ukrainians are hiding from mobilization abroad. Deutsche Welle. Tuan, Y.-F. (1977). Space and Place: The Perspective of Experience. London: E. Arnold.

Ukrainian Pravda (2020, August 3). Ternopil refused strict quarantine: Such blockade was in the days of the Tatars. Ukrainian Pravda. Retrieved from https://www.pravda.com.ua/news/2020/08/3/7261632/

Ukrainian Pravda (2020, August 5). In Kiev there are "velor" restaurants working, and here the transport blockade - the mayor of Ternopil about indignation by a "red zone" and local elections. Ukrainian Pravda. Retrieved from https://www.pravda.com.ua/articles/2020/08/5/7261801/8

Ukrinform (2016, March 25). Another scandal over amber in Volyn. Ukrinform. Retrieved from https:// www.ukrinform.ua/rubric-regions/1988474-na-volini-znovu-skandal-cerez-burstin.html

Ukrinform (2019, April 5). Elections in Transcarpathia: what happened, what will happen and who wants to take revenge. Ukrinform. Retrieved from https://www.ukrinform.ua/rubric-elections/2674956vibori-na-zakarpatti-so-bulo-so-bude-i-hto-hoce-vzati-revans.html

Ukrinform (2021, February 5). Residents of the western regions of the country are the most optimistic. Poll. Ukrinform. Retrieved from https://www.ukrinform.ua/rubric-society/3184814-najoptimisticnisenalastovani-meskanci-zahidnih-regioniv-derzavi.html

Vasiliev, V. (2005). Peasant resistance to collectivization in Ukraine (1930s). History of Ukraine. Littleknown names, events, facts, 31, 140-150.

VRSA (2020). Strategy of Development of the Volyn region for the period 2021-2027. Volyn Regional State Administration. Retrieved from https://www.minregion.gov.ua/wp-content/uploads/2020/04/ volynska-strategiya-rozvytku-volynskoyi-oblasti-na-period-do-2027-roku.pdf

Zanuda, A., \& Dorosh, S. (2015, June 2). Opening of archives: how Russians were relocated to Donbass after the Holodomor. BBC Ukraine. Retrieved from https://www.bbc.com/ukrainian/ society/2015/06/150522_holodomor_donbass_russia_az 